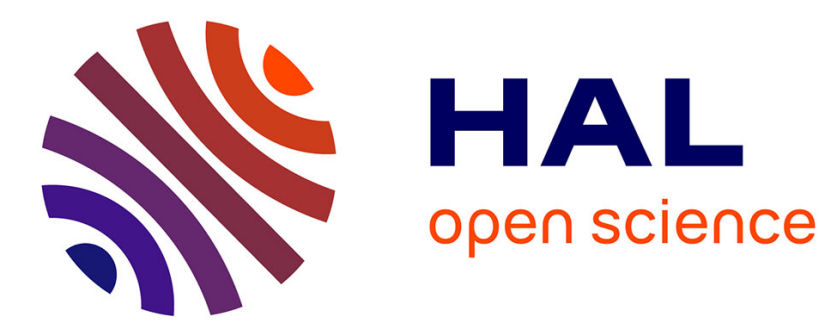

\title{
The effects of fiscal consolidations on the composition of government spending
}

\author{
Moulaye Bamba, Jean-Louis Combes, Alexandru Minea
}

\section{To cite this version:}

Moulaye Bamba, Jean-Louis Combes, Alexandru Minea. The effects of fiscal consolidations on the composition of government spending. Applied Economics, 2020, 52 (14), pp.1517-1532. 10.1080/00036846.2019.1676392 . hal-02887275

\section{HAL Id: hal-02887275 https://hal.science/hal-02887275}

Submitted on 6 Dec 2021

HAL is a multi-disciplinary open access archive for the deposit and dissemination of scientific research documents, whether they are published or not. The documents may come from teaching and research institutions in France or abroad, or from public or private research centers.
L'archive ouverte pluridisciplinaire HAL, est destinée au dépôt et à la diffusion de documents scientifiques de niveau recherche, publiés ou non, émanant des établissements d'enseignement et de recherche français ou étrangers, des laboratoires publics ou privés. 


\title{
THE EFFECTS OF FISCAL CONSOLIDATIONS ON THE COMPOSITION OF GOVERNMENT SPENDING
}

\author{
$\operatorname{Moulaye~Bamba}^{(a)}, \operatorname{Jean}$ Louis $\operatorname{Combes}^{(a)}, \operatorname{Alexandru~Minea}^{(a)(b)(c)}$ \\ (a) CERDI and School of Economics, University Clermont Auvergne, France \\ (b) Department of Economics, Carleton University, Canada \\ (c) Corresponding author: alexandru.minea@uca.fr
}

\begin{abstract}
In response to increasing debt paths, governments often implement fiscal consolidation programs. This paper studies the impact of these programs on the composition of government spending. System-GMM estimations performed on a sample of 53 developed and emerging countries over 1980-2011 reveal that fiscal consolidations significantly reduce the government investment-toconsumption ratio, i.e. a composition effect. Robust to a wide set of tests, including when using the narrative approach to identify fiscal consolidations, this significantly stronger contraction of government investment with respect to government consumption is at work particularly when debt is high and in the low phase of the economic cycle. Therefore, in such contexts, fiscal consolidations aimed at short-run stabilization may hurt the economy in the long-run through their detrimental effect on public investment, calling for a reflection upon how they could be re-designed to allow avoiding such undesirable consequences.
\end{abstract}

JEL Codes: E62, H50

Keywords: fiscal consolidation; government consumption; government investment.

Acknowledgments: We are indebted to the Editor (David Peel) and an anonymous referee for valuable comments on a previous version of our manuscript. We thank the ANR (Agence Nationale de la Recherche) for their financial support through the "Grand Emprunt" and the LABEX IDGM+ (ANR-10-LABX-14-01) mechanism. Usual disclaimers apply. 


\section{Introduction}

To fight the detrimental effects of the recent financial crisis, many governments adopted large demand-based fiscal stimuli. Designed to boost economy activity, these policies resulted into large fiscal deficits and debt-to-GDP ratios. Given the danger on public finance sustainability, governments decided to implement fiscal consolidation programs.

There exists a large and increasing literature on fiscal consolidations. While surveying it is beyond the scope of this paper, important questions related to fiscal consolidations include: (i) the size of the fiscal consolidation episode, see e.g. Giavazzi and Pagano (1995) or Ardagna (2004); (ii) its persistence, see e.g. Drazen (1990), Heylen and Everaert (2000), or Barrios et al. (2010); (iii) its measure, usually based on observed variables such as the cyclically-adjusted primary balance, or on the narrative approach, see e.g. Alesina and Ardagna (1998); Alesina and Ardagna (2010); Cotis et al. (2004); Guajardo et al. (2014) for comparisons of alternative methods; and (iv) the variable that adjusts, namely spending or taxes. On this last point, Afonso and Jalles (2012); Alesina and Ardagna (1998); Alesina and Perotti (1995); McDermott and Wescott (1996), among others, found that successful fiscal consolidations mainly rely on expenditure cuts rather than tax increases, and e.g. Alesina and Ardagna (2013); Alesina et al. (2015, 2018); Heylen et al. (2013); Schaltegger and Feld (2009) conclude that fiscal consolidations led by spending cuts are more likely to generate growth and reduce deficits/debt than those led by tax hikes.

Consequently, focusing on public spending, several contributions investigated the component of public expenditure that should be cut in the process of fiscal consolidation. On the one hand, governments could reduce public investment, which is less effective for debt reduction (Alesina and Perotti, 1995) but politically more acceptable. However, the decline in public investment may hurt overall productivity (Aschauer, 1989), economic growth (Abiad et al., 2016), and welfare (Heijdra and Meijdam, 2002), to the point where, given the current global mild economic conditions, the IMF $(2014,2015)$ advocates for large public investment in infrastructure to sustain the global recovery after the crisis (echoing the 2014 "Juncker Plan" of the European Commission). On the other hand, governments could reduce current spending, which are more efficient for deficit reduction but may affect governments' probability of reelection (Roubini and Sachs, 1989), and raise inequality and poverty (Agnello and Sousa, 2014).

Taking stock of these studies, the goal of this paper is to analyze the effect of fiscal consolidations on the composition of public spending. Despite being of particular importance, given the benefits and costs associated with reducing each type of public spending, this issue remains fairly unexplored with the notable exception of Castro (2017). Compared with Castro (2017), we draw upon Alesina and Ardagna (2013)'s novel measure of fiscal consolidations that accounts for the size and the persistence of the adjustment (instead of a dummy variable as a measure of fiscal consolidations, see also De Haan et al. $\left.(1996)^{1}\right)$. In addition, while Castro (2017) looks at different components of government expenditure in 15 EU countries, we specifically focus on the government investment-toconsumption ratio to assess the relative change between them. Using the system-GMM estimator of Blundell and Bond (1998) that properly tackles endogeneity, our findings based on a large sample of 53 developed and emerging countries over the 1980-2011 period are as follows.

First, while we confirm that fiscal consolidations reduce both the government investment-toGDP ratio (Balassone and Franco (1999); De Haan et al. (1996); Turrini (2004); Välilä and Mehrotra

\footnotetext{
${ }^{1}$ Alternatively, Oxley and Martin (1991) draw upon descriptive statistics.
} 
$(2005))^{2}$ and the government consumption-to-GDP ratio (Castro (2017)) - a level effect, we reveal that the government investment-to-consumption ratio equally significantly declines - a composition effect. Consequently, government investment is found to decrease more than government consumption during fiscal consolidations.

Second, we investigate the robustness of this finding with respect to an important source of debate, namely the definition of fiscal consolidations. Moving away from Alesina and Ardagna (2013)'s definition (used in our baseline analysis), we consider different lengths of the period used to define a fiscal consolidation episode, as well as endogenous definitions of fiscal consolidations following Yang et al. (2015). Estimations with these alternative measures confirm the existence of a composition effect, and this decline of the government investment-to-consumption ratio remains robust when further controlling for periods unrelated to fiscal consolidations, for a wide set of additional control variables, or when drawing upon an alternative method, namely the narrative approach, to identify fiscal consolidations.

Third, we explore the sensitivity of the composition effect with respect to fiscal conditions, the overall state of the economy, and across different components of government consumption. Estimations show that fiscal consolidations significantly reduce the government investment-to-consumption ratio only in a context of high debt and in the low phase of the economic cycle. Next, we find that the contraction of the government investment-to-consumption ratio can be up to four times higher in non-OECD compared with OECD countries following fiscal consolidations. Finally, looking at the effects of fiscal consolidations on the components of government consumption, we reveal that while the contraction of government investment is significantly stronger than that of public wages, and health government spending, fiscal consolidations are associated with a higher ratio of government investment to transfers \& subsidies, suggesting a relatively stronger decline of the latter with respect to the former.

The paper is organized as follows. Section 2 discusses the measurement of fiscal consolidation episodes, Section 3 presents the data and the methodology, Section 4 reports the baseline results, Section 5 analyzes their robustness, Section 6 explores possible heterogeneities, and Section 7 contains some conclusive remarks.

\section{Identification of fiscal consolidation episodes}

\section{$2.1 \quad$ Fiscal impulse measurement}

We define a discretionary fiscal consolidation episode following the cyclically-adjusted primary balance (CAPB) approach developed by Blanchard (1990), and adopted by Alesina and Perotti (1995; 1997) and Alesina and Ardagna(1998; 2013), which consists of extracting the discretionary part of fiscal variables, excluding interest payments. Following Alesina and Perotti (1995), we build the CAPB in two steps. First, we regress for each country revenues $R_{t}$ and spending $G_{t}$ (in ratio of GDP) on a linear time trend (TREND) and the unemployment rate $U_{t}$, to obtain the

\footnotetext{
${ }^{2}$ Following the pioneering work of Musgrave (1939), Blanchard and Giavazzi (2004), among others, defended the idea of a "golden rule" of public finance, for protecting public investment by excluding it from the accountancy of the Stability and Growth Pact (SGP) 3\% deficit rule. For a theoretical analysis of the golden rule, see e.g. Minea and Villieu (2009).
} 
cyclically-adjusted revenues and spending (in ratio of GDP)

$$
\begin{aligned}
& R_{t}=\alpha_{0}+\beta_{0} T R E N D+\gamma_{0} U_{t}+\epsilon_{t}, \\
& G_{t}=\alpha_{1}+\beta_{1} T R E N D+\gamma_{1} U_{t}+u_{t} .
\end{aligned}
$$

Using the estimated parameters we compute what would have been revenues and spending in time $t$ if the unemployment rate has remained constant between $t$ and $t-1$

$$
\begin{aligned}
& R_{t}^{*}\left(U_{t-1}\right)=\hat{\alpha_{0}}+\hat{\beta_{0}} T R E N D+\hat{\gamma_{0}} U_{t-1}, \\
& G_{t}^{*}\left(U_{t-1}\right)=\hat{\alpha_{1}}+\hat{\beta_{1}} T R E N D+\hat{\gamma_{1}} U_{t-1} .
\end{aligned}
$$

Second, we construct the discretionary change in the fiscal balance as the difference between the cyclically-adjusted fiscal variables in year $t$, and their respective values in year $t-1$

$$
C A P B_{t}=\left[R_{t}^{*}-R_{t-1}\right]-\left[G_{t}^{*}-G_{t-1}\right] .
$$

\subsection{Definition of fiscal consolidation episodes}

There are several ways to define a fiscal consolidation episode, usually based on a threshold value related to the size or the persistence of the change in the fiscal policy (see (Yang et al., 2015), for a summary of different definitions). We define our fiscal consolidation episode following Alesina and Ardagna (2013).

Definition 1. A fiscal consolidation is either:

(1) the value of the fiscal retrenchment over a 2-year period if the ratio CAPB/GDP improves each year, and the cumulative improvement is of at least 2 percentage points, or

(2) the value of the fiscal retrenchment over a 3-year or more period if the ratio CAPB/GDP improves each year, and the cumulative improvement is of at least 3 percentage points.

This definition has several merits. First, it uses the novel approach that includes both the size and the persistence in the assessment of fiscal consolidations, whereas the size refers to the amplitude (intensity) of the CAPB/GDP change, and the persistence captures the length of the adjustment. Considering both features can overcome the famous "stop-and-go" problem in the fiscal consolidations literature. Second, it ensures the comparability of our analysis with the recent literature on fiscal consolidations that widely draws upon this definition (see e.g. Alesina and Ardagna(2010; 2013); Leigh et al., 2010; Guajardo et al., 2014; Yang et al., 2015).

We identified 123 fiscal consolidation episodes during our considered period of 32 years. Figure 1 depicts the distribution of these episodes in percentage of the total number of fiscal consolidations in our sample, based on their size and persistence. Among them, 65 fiscal consolidations (52.85\%) last 2 years, 19 (15.45\%) last 3 years, and so on (see the Appendix for the list of fiscal consolidations); and 50 fiscal consolidations $(40.65 \%)$ improve the fiscal balance between $2-4$ percentage points of GDP, 38 (30.89\%) between 4-6 percentage points of GDP, and so forth. 
Figure 1 - Distribution of the fiscal consolidation episodes by persistence and size
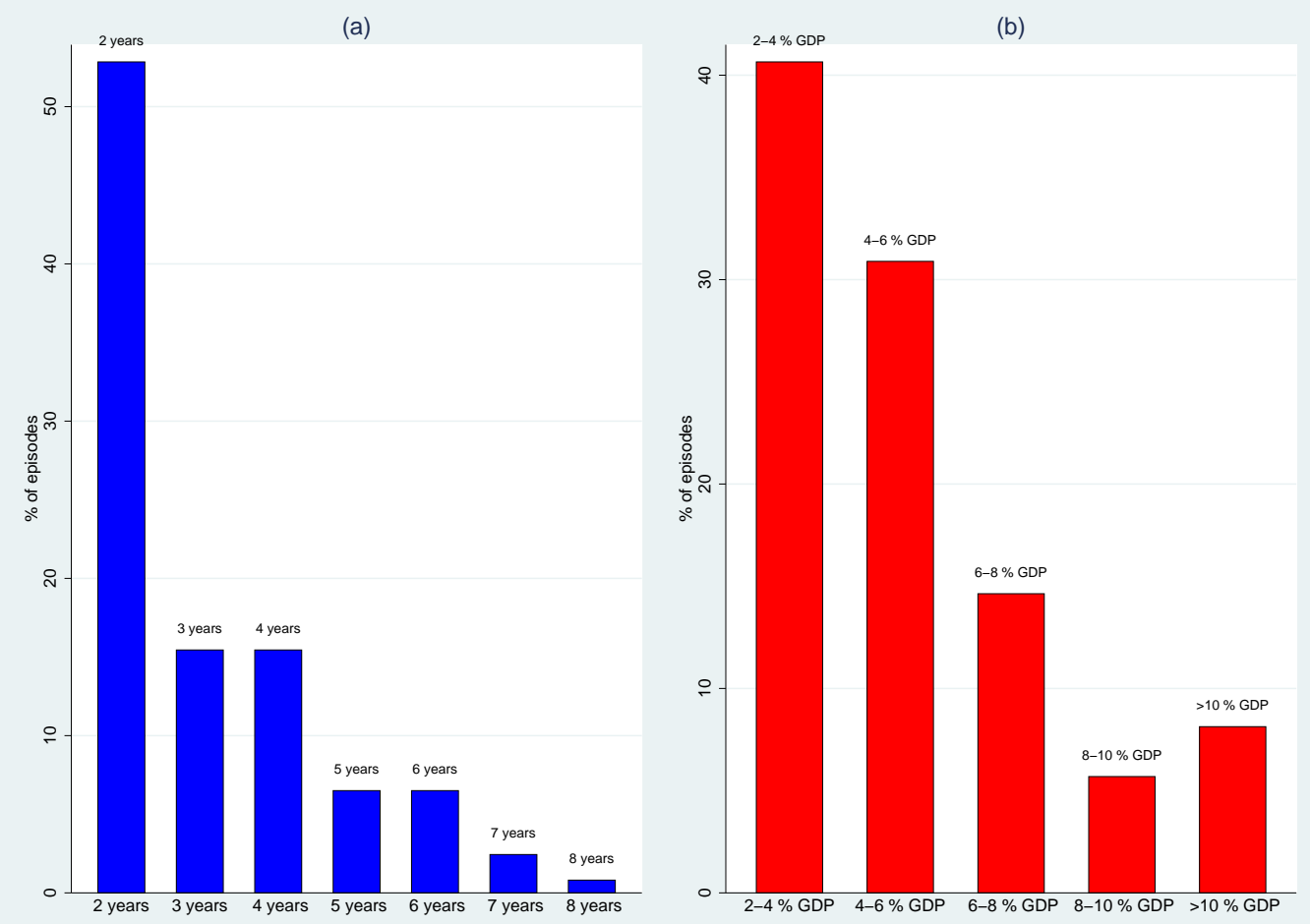

(a): the percentage of fiscal consolidations by length. (b): the percentage of fiscal consolidations by size.

\section{Data, and methodology}

\subsection{Data}

Our study is performed in an unbalanced panel covering the period 1980-2011. Using Mauro et al. (2015) database, which provides the widest coverage of fiscal aggregates to our knowledge, we obtained data for 56 developed and emerging countries. However, the need of unemployment data to build the CAPB forced us to exclude three countries, leading to a sample of 53 countries. We refrained from considering developing countries in our sample, given the high quality data on unemployment required by the computation of the CAPB.

Our dependent variable is the ratio between government investment $(G I)$ and government final consumption $(G C)$. Government investment includes government expenditure devoted to fixed and durable goods, such as roads, energy, and telecommunications infrastructures (source: (IMF, 2017) database). According to the National Accounting System, government final consumption encompasses all current expenditure used for purchasing goods and services, excluding the military materials that are included in the government investment, but including compensation of employees and interest payments (source: WDI, 2016).

Control variables are those that can impact government spending, and may even affect fiscal consolidations, namely: (i) debt $(D E B T)$, (ii) real growth $(G R O W T H)$, (iii) trade openness (TRADE), (iv) private investment (IPRIV), (v) a dummy variable capturing the impact of being 
under an IMF program $(I M F P)$, (vi) transfers \& subsidies $(S U B)$, and (vii) government stability $(G O V)$; except for real growth and the IMF program dummy, all variables are in ratio of GDP. The Appendix reports the sources, definitions, and descriptive statistics of variables.

\subsection{The econometric model}

We estimate the following dynamic model with country-fixed effects

$$
\frac{G I_{i t}}{G C_{i t}}=\alpha+\rho \frac{G I_{i t-1}}{G C_{i t-1}}+\beta C O N S_{i t}+\gamma^{k} X_{i t}^{k}+\lambda_{i}+\xi_{i t} .
$$

The dependent variable $\frac{G I_{i t}}{G C_{i t}}$ is the ratio between government investment and consumption, $\rho$ accounts for inertia in the dynamics of the ratio $\frac{G I_{i t}}{G C_{i t}}, \gamma^{k}$ is the marginal effect of each of the $k$ control variable, $\lambda_{i}$ are country-fixed effects, and $\xi_{i t}$ is the error term. The coefficient of interest is $\beta$, which captures the effect of our fiscal consolidation variable $(C O N S)$ on $\frac{G I_{i t}}{G C_{i t}}$.

We use the Blundell and Bond (1998) system-GMM estimator in our baseline model, for the following reasons. First, OLS lead to bias estimates, since they do not account for country-unobserved heterogeneity. However, the country-fixed effects estimator is also inconsistent when the time panel dimension is short, due to the correlation between the lagged dependent variable and the error terms (Nickell, 1981). Besides, Hauk and Wacziarg (2009) emphasize that the fixed-effects estimator worsens the bias related to measurement errors, and undervalues the impact of covariates in a dynamic panel setting with time-persistent regressors, as in our case. Second, while the difference-GMM estimator copes with the heterogeneity bias in the first-difference step and mitigates endogeneity issues, it suffers from a weak-instrument problem due to the weak correlation between lagged variables in level and variables in first-difference in the presence of time-persistence (Alonso-Borrego and Arellano, 1999). Third, the system-GMM provides more consistent and efficient estimators than the difference-GMM in dynamic panels in the presence of highly-persistent variables over time ((Blundell and Bond, 1998) and (Blundell et al., 2001)). Finally, the system-GMM provides a smaller bias (in terms of size) than the difference-GMM or the fixed-effects estimators, even when the required stationary condition is doubtful (Hauk and Wacziarg, 2009).

\section{Results}

Our results are presented in Table 1. When implementing the system-GMM estimator, we overcome the proliferation of instruments by collapsing the matrix of instruments to have less instruments than countries (Roodman, 2009). ${ }^{3}$ In addition to the strong effect of the lagged depending variable, the use of the system-GMM estimator is equally supported by usual diagnostic tests, namely valid instruments (see the p-value of the Hansen test), and the presence (absence) of first-order (secondorder) autocorrelation in the dependent variable as shown by the $\operatorname{AR}(1)(\operatorname{AR}(2))$ test.

As shown by regression (1), fiscal consolidations significantly decrease the ratio $G I / G C$. Corroborated with the decline of $G I$ and $G C$ (see Tables 13-14 in the Appendix), it comes that the relative change in the government investment ratio is stronger than the relative change in the government consumption ratio. ${ }^{4}$ With respect to an early literature, which insisted on the fact that

\footnotetext{
${ }^{3}$ In addition, we report that the variables are stationary (results are available upon request).

${ }^{4}$ According to the last column of Table 1, an improvement of the CAPB of 1.70 percentage points of GDP (the average $\mathrm{CAPB}$ improvement during fiscal consolidations) reduces the $G I / G C$ ratio by roughly 4 percentage points
} 
Table 1 - The effect of fiscal consolidations on the GI/GC ratio

\begin{tabular}{|c|c|c|c|c|c|c|c|}
\hline & (1) & $(2)$ & (3) & (4) & $(5)$ & (6) & $(7)$ \\
\hline$\frac{G I_{i t-1}}{G C_{i t-1}}$ & $\begin{array}{c}0.884^{* * *} \\
(0.101)\end{array}$ & $\begin{array}{c}0.797^{* * *} \\
(0.118)\end{array}$ & $\begin{array}{c}0.805^{* * *} \\
(0.103)\end{array}$ & $\begin{array}{c}0.795^{* * *} \\
(0.097)\end{array}$ & $\begin{array}{c}0.797^{* * *} \\
(0.095)\end{array}$ & $\begin{array}{c}0.766^{* * *} \\
(0.074)\end{array}$ & $\begin{array}{c}0.766^{* * *} \\
(0.071)\end{array}$ \\
\hline$C O N S_{i t}$ & $\begin{array}{c}-0.493^{* *} \\
(0.200)\end{array}$ & $\begin{array}{c}-0.484^{* * *} \\
(0.176)\end{array}$ & $\begin{array}{c}-0.515^{* * *} \\
(0.165)\end{array}$ & $\begin{array}{c}-0.458^{* * *} \\
(0.146)\end{array}$ & $\begin{array}{c}-0.472^{* * *} \\
(0.141)\end{array}$ & $\begin{array}{c}-0.579^{* * *} \\
(0.166)\end{array}$ & $\begin{array}{c}-0.551^{* * *} \\
(0.192)\end{array}$ \\
\hline$D E B T_{i t-1}$ & & $\begin{array}{c}-0.050^{* *} \\
(0.021)\end{array}$ & $\begin{array}{c}-0.048^{* * *} \\
(0.016)\end{array}$ & $\begin{array}{c}-0.048^{* * *} \\
(0.017)\end{array}$ & $\begin{array}{c}-0.053^{* * *} \\
(0.013)\end{array}$ & $\begin{array}{c}-0.049^{* * *} \\
(0.018)\end{array}$ & $\begin{array}{c}-0.053^{* * *} \\
(0.020)\end{array}$ \\
\hline GROWT $_{i t}$ & & & $\begin{array}{l}0.107^{*} \\
(0.055)\end{array}$ & $\begin{array}{l}0.100^{*} \\
(0.052)\end{array}$ & $\begin{array}{c}0.212^{* * *} \\
(0.071)\end{array}$ & $\begin{array}{c}0.184^{* *} \\
(0.083)\end{array}$ & $\begin{array}{l}0.177^{* *} \\
(0.087)\end{array}$ \\
\hline$T R A D E_{i t}$ & & & & $\begin{array}{l}-0.005 \\
(0.020)\end{array}$ & $\begin{array}{c}-0.014 \\
(0.017)\end{array}$ & $\begin{array}{c}0.007 \\
(0.022)\end{array}$ & $\begin{array}{c}0.007 \\
(0.023)\end{array}$ \\
\hline$I P R I V_{i t}$ & & & & & $\begin{array}{c}-0.307^{* *} \\
(0.147)\end{array}$ & $\begin{array}{l}-0.257^{*} \\
(0.149)\end{array}$ & $\begin{array}{c}-0.270^{*} \\
(0.158)\end{array}$ \\
\hline$I M F P_{i t}$ & & & & & & $\begin{array}{c}0.517 \\
(0.591)\end{array}$ & $\begin{array}{c}0.440 \\
(0.616)\end{array}$ \\
\hline$\frac{S U B_{i t}}{G C_{i t}}$ & & & & & & $\begin{array}{c}0.001 \\
(0.000)\end{array}$ & $\begin{array}{c}0.000 \\
(0.000)\end{array}$ \\
\hline$G O V_{i t}$ & & & & & & & $\begin{array}{l}-0.096 \\
(0.079)\end{array}$ \\
\hline$N$ & 817 & 817 & 817 & 817 & 817 & 817 & 817 \\
\hline groups & 43 & 43 & 43 & 43 & 43 & 43 & 43 \\
\hline $\mathrm{N}$ _instr & 8 & 9 & 12 & 15 & 20 & 24 & 25 \\
\hline $\mathrm{AR}(1)$ & 0.000 & 0.001 & 0.000 & 0.000 & 0.001 & 0.000 & 0.000 \\
\hline $\operatorname{AR}(2)$ & 0.510 & 0.570 & 0.612 & 0.621 & 0.529 & 0.612 & 0.609 \\
\hline Hansen & 0.252 & 0.470 & 0.568 & 0.743 & 0.870 & 0.867 & 0.768 \\
\hline
\end{tabular}

Standard errors are in brackets. Regressions are based on the Blundell-Bond estimator. Lagged $G I / G C$ is predetermined, lagged debt, government stability and IMF program are exogenous, and the remaining covariates are endogenous.

${ }^{*} p<0.1,{ }^{* *} p<0.05,{ }^{* * *} p<0.01$ 
fiscal consolidations tend to reduce government investment (see e.g. Oxley and Martin (1991), or De Haan et al. (1996)), the composition effect that we reveal suggests that fiscal consolidations lead to a more important cut in government investment than in government consumption.

\section{Robustness}

In this section we explore the robustness of our baseline results in several ways.

\subsection{Alternative definitions of fiscal consolidations}

In Alesina and Ardagna (2013)'s definition used to compute fiscal consolidations in the baseline specification, the threshold is somehow arbitrary. To check whether our findings are sensitive to a particular threshold, we consider the following alternative definitions of fiscal consolidations.

Table 2 - Fiscal consolidations and the GI/GC ratio: alternative definitions of thresholds

\begin{tabular}{|c|c|c|c|}
\hline \multirow{3}{*}{ Alternatives } & \multicolumn{3}{|l|}{ Threshold criteria } \\
\hline & threshold 1 & threshold 2 & threshold 3 \\
\hline & (1) & $(2)$ & $(3)$ \\
\hline$\frac{G I_{i t-1}}{G C_{i t-1}}$ & $0.790^{* * *}(0.139)$ & $0.789^{* * *}(0.147)$ & $0.738^{* * *}(0.179)$ \\
\hline$C O N S_{i t}$ & $-0.390 * *(0.197)$ & $-0.414^{* *}(0.194)$ & $-0.432^{* *}(0.194)$ \\
\hline $\mathrm{N}$ & 1124 & 1124 & 1124 \\
\hline Groups & 47 & 47 & 47 \\
\hline $\mathrm{N} \_$instr & 18 & 18 & 22 \\
\hline $\operatorname{AR}(1)$ & 0.001 & 0.001 & 0.004 \\
\hline $\operatorname{AR}(2)$ & 0.570 & 0.576 & 0.609 \\
\hline Hansen & 0.846 & 0.829 & 0.859 \\
\hline Controls & Yes & Yes & Yes \\
\hline
\end{tabular}

Standard errors are in brackets. Regressions are based on the Blundell-Bond estimator. Lagged $G I / G C$ is predetermined, lagged debt, government stability and IMF program are exogenous, and the remaining covariates are endogenous. We introduce lagged debt, GDP growth, trade, private investment, IMF program and government stability as explanatory variables.

${ }^{*} p<0.1,{ }^{* *} p<0.05,{ }^{* * *} p<0.01$

First, compared with the baseline definition of 2 years \& 2 percentage points (hereafter pp), or 3 years \& $3 \mathrm{pp}$, we increase the threshold to stress the fact that the change in fiscal policy is discretionary. With "threshold 1", a fiscal consolidation episode is signalled by either 2 years of consecutive CAPB improvement of at least 2.5 pp of GDP, or 3 years \& 3.5 pp improvement; while for "threshold 2" ("threshold 3 "), the corresponding numbers are 2 years \& 3 pp (4 pp), or 3 years and $4 \mathrm{pp}(5 \mathrm{pp})$. As shown by columns (1)-(3) in Table 2, using these different thresholds to define fiscal consolidations has little impact on their effect on the $G I / G C$ ratio compared with our baseline results.

of GDP in the long-run. 
Table 3 - Fiscal consolidations and the GI/GC ratio: endogenous thresholds and an alternative consolidation measure

\begin{tabular}{|c|c|c|c|c|}
\hline \multirow{3}{*}{ Altenatives } & \multicolumn{3}{|c|}{ Endogenous threshold } & \multirow{2}{*}{$\begin{array}{l}\text { CAPB concept } \\
\text { Terms of Trade }\end{array}$} \\
\hline & Def1 & Def2 & Def3 & \\
\hline & $(1)$ & $(2)$ & $(3)$ & $(4)$ \\
\hline Single year & 1 & $3 / 4$ & 2 & \\
\hline Multiple years & $1 / 4,1,3 / 2$ & $1 / 4,1,3 / 2$ & $3 / 4,2,3$ & \\
\hline$\frac{G I_{i t-1}}{G C_{i t-1}}$ & $0.768^{* * *}(0.031)$ & $0.771^{* * *}(0.036)$ & $0.803^{* * *}(0.018)$ & $0.746^{* * *}(0.050)$ \\
\hline$C O N S_{i t}$ & $-0.225^{* * *}(0.077)$ & $-0.222 * * *(0.079)$ & $-0.181 * * *(0.061)$ & $-0.221^{* *}(0.072)$ \\
\hline $\mathrm{N}$ & 1124 & 1124 & 1124 & 1124 \\
\hline Groups & 47 & 47 & 47 & 47 \\
\hline $\mathrm{N}_{\text {_instr }}$ & 26 & 26 & 30 & 19 \\
\hline $\operatorname{AR}(1)$ & 0.000 & 0.000 & 0.000 & 0.000 \\
\hline $\operatorname{AR}(2)$ & 0.538 & 0.544 & 0.571 & 0.572 \\
\hline Hansen & 0.443 & 0.394 & 0.788 & 0.819 \\
\hline Controls & Yes & Yes & Yes & Yes \\
\hline
\end{tabular}

Standard errors are in brackets. Regressions are based on the Blundell-Bond estimator. Lagged $G I / G C$ is predetermined, lagged debt, government stability and IMF program are exogenous, and the remaining covariates are endogenous. We introduce lagged debt, GDP growth, trade, private investment, IMF program and government stability as explanatory variables.

${ }^{*} p<0.1,{ }^{* *} p<0.05,{ }^{* * *} p<0.01$ 
Second, since countries do not present the same deficit level or the same structural capacity to reduce it, we allow the threshold to vary with respect to the country-specific average (me) and standard deviation (sd) in CAPB changes. Following Yang et al. (2015), "def 1" designs a fiscal consolidation episode defined as: (i) a one-year fiscal consolidation, if the CAPB improvement is at least me+sd for this year, except if the CAPB falls by me+sd in the previous or next year; or (ii) a two-year (three-year or more) fiscal consolidation, if the CAPB improves in the first year by at least me+1/4sd and the cumulative improvement is of at least me+sd (me+3/2sd); and (iii) a fiscal consolidation stops if the CAPB does not improve in one year or improves by less than me $+1 / 4 \mathrm{sd}$, and the cumulative improvement over the following year is of at least me $+1 / 4$ sd; however, the fiscal consolidation continues if the variation of the CAPB ranges between me $+1 / 4 \mathrm{sd}$ and me- $1 / 4 \mathrm{sd}$ in this year. Similarly, "def2" and "def3" use the multiples $(3 / 4,1 / 4,1,3 / 2)$ and $(2,3 / 4,2,3)$ of the standard deviation to construct alternative fiscal consolidations measures. As shown by columns (1)-(3) of Table 3, despite some magnitude loss, fiscal consolidations are still significantly related with a decrease in the $G I / G C$ ratio.

Third, we further account for country-specific heterogeneities, and particularly for international trade shocks on fiscal policy, by including the terms of trade, in addition to the unemployment rate, when computing the CAPB. As such, a fiscal consolidation episode is signaled by: (i) a 2-year period in which the CAPB improves each year and the cumulative improvement is of at least $2 *$ (mesd) pp; or (ii) a 3-year or more period in which the CAPB improves each year and the cumulative improvement is of at least $3^{*}(\mathrm{me}-\mathrm{sd}) \mathrm{pp}$. Despite a lower magnitude compared with the baseline, column (4) of Table 3 confirms yet again the negative effect of fiscal consolidations on the $G I / G C$ ratio.

\subsection{A "Placebo-test" of fiscal consolidations}

Our baseline specification includes only changes in the CAPB during fiscal consolidation episodes. Indeed, we assume that the effect of fiscal consolidations is specific, and not related to discretionary changes in fiscal policy during "normal" times. To take a closer look at this assumption, we introduce in model (6) the change in CAPB during the periods of no fiscal consolidations $\left(N C O N S_{i t}\right)$, following Alesina and Ardagna (2013). Results in Table 4 support our assumption, since the effect of $N C O N S$ is mostly not significant. More importantly, we confirm the bias against public investment, since the effect of fiscal consolidations on the $G I / G C$ ratio remains significant and negative.

\subsection{Additional control variables}

We introduce several additional control variables related to the financing of the economic development (foreign direct investment, and aid), to account for a crowding-in/out effect. In addition, we account for institutions (the political tendency of the government party, the political color of the legislature, and the electoral period), to control for potential partisan cycles. As shown by Table 15 in the Appendix, the negative effect of fiscal consolidations on the ratio $G I / G C$ is still at work when controlling for these additional variables. 
Table 4 - The effect of fiscal consolidations on the GI/GC ratio: no consolidation episodes

\begin{tabular}{lccccccc}
\hline \hline & $(1)$ & $(2)$ & $(3)$ & $(4)$ & $(5)$ & $(6)$ & $(7)$ \\
\hline$G I_{i t-1}$ & $0.895^{* * *}$ & $0.939^{* * *}$ & $0.945^{* * *}$ & $0.931^{* * *}$ & $0.928^{* * *}$ & $0.931^{* * *}$ & $0.856^{* * *}$ \\
& $(0.176)$ & $(0.106)$ & $(0.087)$ & $(0.088)$ & $(0.106)$ & $(0.089)$ & $(0.164)$ \\
& & & & & & & \\
CON $S_{i t}$ & $-0.439^{* *}$ & $-0.488^{* *}$ & $-0.405^{* *}$ & $-0.363^{* *}$ & $-0.393^{* *}$ & $-0.354^{* *}$ & $-0.395^{* *}$ \\
& $(0.206)$ & $(0.216)$ & $(0.167)$ & $(0.175)$ & $(0.175)$ & $(0.178)$ & $(0.179)$ \\
& & & & & & & \\
NCONS $S_{i t}$ & -0.162 & -0.187 & $-0.184^{* *}$ & $-0.166^{*}$ & $-0.155^{* *}$ & -0.134 & -0.121 \\
& $(0.122)$ & $(0.115)$ & $(0.091)$ & $(0.085)$ & $(0.068)$ & $(0.082)$ & $(0.095)$ \\
\hline$N$ & 1151 & 1151 & 1151 & 1151 & 1151 & 1151 & 1151 \\
groups & 48 & 48 & 48 & 48 & 48 & 48 & 48 \\
N_instr & 11 & 9 & 14 & 17 & 21 & 21 & 26 \\
AR $(1)$ & 0.002 & 0.000 & 0.000 & 0.000 & 0.000 & 0.000 & 0.003 \\
AR $(2)$ & 0.676 & 0.517 & 0.566 & 0.596 & 0.774 & 0.730 & 0.736 \\
Hansen & 0.451 & 0.489 & 0.676 & 0.781 & 0.853 & 0.867 & 0.839 \\
\hline \hline Stang
\end{tabular}

Standard errors are in brackets. Regressions are based on the Blundell-Bond estimator. Starting from the most parsimonious specification (column 1), we progressively introduce lagged debt, GDP growth, trade, private investment, IMF program, and government stability in columns (2)-(7).

${ }^{*} p<0.1,{ }^{* *} p<0.05,{ }^{* * *} p<0.01$

\subsection{An alternative identification of fiscal consolidations: the narrative approach}

So far, we draw upon Alesina and Ardagna (2013) to measure fiscal consolidations. However, several studies, including the contributions of Leigh et al. (2010), Devries et al. (2011), and Guajardo et al. (2014), draw upon the "narrative approach" (Friedman and Schwartz (1963); Romer and Romer (1989)) to identify fiscal consolidations. In this subsection, we follow these studies, and explore the robustness of our results to the use of the narrative approach. To this end, drawing upon the data provided by Devries et al. (2011) and David and Leigh (2018), we compile a database of fiscal consolidations episodes; compared with the initial sample of 53 countries, data on fiscal consolidations identified using the narrative approach cover 24 countries (17 OECD countries and 7 emerging countries mainly from Latin America). Irrespective of the set of control variables, estimations reported in Table 5 show that fiscal consolidations significantly decrease the ratio $G I / G C .{ }^{5}$ Consequently, our composition effect is still at work when using the narrative approach to identify fiscal consolidations.

\section{Heterogeneity}

This section analyzes the sensitivity of the effect of fiscal consolidations on the $G I / G C$ ratio with respect to fiscal conditions (i.e. the debt level), the overall state of the economy (in the short-run: the position in the business cycle, and in the long-run: the development stage), and across different

\footnotetext{
${ }^{5}$ We report that fiscal consolidations measured as in our baseline analysis are yet again found to robustly decrease the $G I / G C$ ratio when performing the estimations for the reduced sample of 24 countries (result are available upon request).
} 
Table 5 - The effect of fiscal consolidations (narrative approach) on the GI/GC ratio

\begin{tabular}{|c|c|c|c|c|c|c|c|c|}
\hline & (1) & $(2)$ & (3) & (4) & $(5)$ & (6) & (7) & (8) \\
\hline$\frac{G I_{i t-1}}{G C_{i t-1}}$ & $\begin{array}{l}0.417^{* *} \\
(0.183)\end{array}$ & $\begin{array}{l}0.587^{* *} \\
(0.263)\end{array}$ & $\begin{array}{c}0.766^{* * *} \\
(0.240)\end{array}$ & $\begin{array}{c}0.896^{* * *} \\
(0.105)\end{array}$ & $\begin{array}{c}0.902^{* * *} \\
(0.056)\end{array}$ & $\begin{array}{c}0.954^{* * *} \\
(0.155)\end{array}$ & $\begin{array}{c}0.831^{* * *} \\
(0.135)\end{array}$ & $\begin{array}{c}0.849^{* * *} \\
(0.062)\end{array}$ \\
\hline$C O N S_{i t}$ & $\begin{array}{c}-0.353^{* *} \\
(0.156)\end{array}$ & $\begin{array}{c}-0.477^{* * *} \\
(0.176)\end{array}$ & $\begin{array}{c}-0.616^{* * *} \\
(0.235)\end{array}$ & $\begin{array}{c}-0.731^{* *} \\
(0.285)\end{array}$ & $\begin{array}{c}-0.763^{* *} \\
(0.350)\end{array}$ & $\begin{array}{c}-0.651^{* *} \\
(0.296)\end{array}$ & $\begin{array}{c}-0.632^{* *} \\
(0.321)\end{array}$ & $\begin{array}{c}-0.680^{* * *} \\
(0.263)\end{array}$ \\
\hline$D E B T_{i t-1}$ & & $\begin{array}{l}-0.025 \\
(0.033)\end{array}$ & $\begin{array}{l}-0.031 \\
(0.030)\end{array}$ & $\begin{array}{l}-0.016 \\
(0.024)\end{array}$ & $\begin{array}{c}-0.011 \\
(0.017)\end{array}$ & $\begin{array}{l}-0.024 \\
(0.026)\end{array}$ & $\begin{array}{l}-0.005 \\
(0.025)\end{array}$ & $\begin{array}{l}-0.007 \\
(0.027)\end{array}$ \\
\hline$G_{R O W T} H_{i t}$ & & & $\begin{array}{c}-0.031 \\
(0.079)\end{array}$ & $\begin{array}{c}0.054 \\
(0.091)\end{array}$ & $\begin{array}{l}0.237^{* *} \\
(0.112)\end{array}$ & $\begin{array}{c}0.052 \\
(0.131)\end{array}$ & $\begin{array}{c}0.283^{* * *} \\
(0.080)\end{array}$ & $\begin{array}{l}0.709^{*} \\
(0.402)\end{array}$ \\
\hline$T R A D E_{i t}$ & & & & $\begin{array}{c}-0.014 \\
(0.024)\end{array}$ & $\begin{array}{l}-0.015 \\
(0.035)\end{array}$ & $\begin{array}{l}-0.011 \\
(0.027)\end{array}$ & $\begin{array}{l}-0.019 \\
(0.026)\end{array}$ & $\begin{array}{c}-0.097^{*} \\
(0.056)\end{array}$ \\
\hline$I P R I V_{i t}$ & & & & & $\begin{array}{c}-0.604^{* *} \\
(0.254)\end{array}$ & $\begin{array}{l}-0.354^{*} \\
(0.194)\end{array}$ & $\begin{array}{c}-0.586^{* * *} \\
(0.200)\end{array}$ & $\begin{array}{c}-1.182^{* *} \\
(0.549)\end{array}$ \\
\hline$I M F P_{i t}$ & & & & & & $\begin{array}{c}-0.970 \\
(1.706)\end{array}$ & $\begin{array}{c}-0.232 \\
(1.275)\end{array}$ & $\begin{array}{l}-0.703 \\
(0.802)\end{array}$ \\
\hline$\frac{S U B_{i t}}{G C_{i t}}$ & & & & & & & $\begin{array}{c}0.000 \\
(0.001)\end{array}$ & $\begin{array}{c}0.000 \\
(0.001)\end{array}$ \\
\hline$G O V_{i t}$ & & & & & & & & $\begin{array}{l}-0.099 \\
(0.101)\end{array}$ \\
\hline$N$ & 526 & 526 & 526 & 526 & 526 & 526 & 526 & 526 \\
\hline groups & 24 & 24 & 24 & 24 & 24 & 24 & 24 & 24 \\
\hline N_instr & 15 & 16 & 16 & 15 & 17 & 18 & 21 & 17 \\
\hline $\mathrm{AR}(1)$ & 0.061 & 0.058 & 0.025 & 0.006 & 0.005 & 0.013 & 0.015 & 0.010 \\
\hline $\mathrm{AR}(2)$ & 0.138 & 0.116 & 0.125 & 0.104 & 0.160 & 0.103 & 0.113 & 0.191 \\
\hline Hansen & 0.594 & 0.245 & 0.309 & 0.268 & 0.165 & 0.819 & 0.301 & 0.802 \\
\hline
\end{tabular}

Standard errors are in brackets. Regressions are based on the Blundell-Bond estimator. Lagged $G I / G C$ is predetermined, lagged debt, government stability and IMF program are exogenous, and the remaining covariates are endogenous.

${ }^{*} p<0.1,{ }^{* *} p<0.05,{ }^{* * *} p<0.01$ 
components of government spending.

\subsection{Fiscal conditions: the debt level}

Fiscal consolidations are usually designed to reduce public debt. Consequently, it is appealing to see if their effect depends on the debt level. We use the median of the distribution of the average debt for each consolidation period (equal to $53 \%$, in ratio of GDP) to differentiate between fiscal consolidations arising in high-debt $\left(C O N S_{i t}^{H D}\right)$ and low-debt $\left(C O N S_{i t}^{L D}\right)$ contexts. According to Table 6, fiscal consolidations significantly reduce the $G I / G C$ ratio only in a context of high debt, consistent with previous findings of strong public investment contraction in damaged fiscal stance (see e.g. (Bacchiocchi et al., 2011)).

Table 6 - The effect of fiscal consolidations on the GI/GC ratio: debt level sensitivity

\begin{tabular}{lcccccccc}
\hline \hline & $(1)$ & $(2)$ & $(3)$ & $(4)$ & $(5)$ & $(6)$ & $(7)$ & $(8)$ \\
\hline$G I_{i t-1}$ & $0.974^{* * *}$ & $0.949^{* * *}$ & $0.940^{* * *}$ & $0.957^{* * *}$ & $0.950^{* * *}$ & $0.933^{* * *}$ & $0.937^{* * *}$ & $0.872^{* * *}$ \\
& $(0.161)$ & $(0.118)$ & $(0.107)$ & $(0.081)$ & $(0.057)$ & $(0.061)$ & $(0.066)$ & $(0.063)$ \\
& & & & & & & & \\
CONS $S^{H D}$ & $-1.052^{* * *}$ & & $-0.989^{* * *}$ & $-0.999^{* * *}$ & $-0.915^{* * *}$ & $-0.898^{* * *}$ & $-0.883^{* * *}$ & $-0.839^{* * *}$ \\
& $(0.297)$ & & $(0.260)$ & $(0.239)$ & $(0.241)$ & $(0.231)$ & $(0.235)$ & $(0.290)$ \\
& & & & & & & & \\
CONS $S^{L D}$ & & 0.007 & 0.002 & 0.058 & 0.077 & 0.131 & 0.133 & 0.060 \\
& & $(0.209)$ & $(0.210)$ & $(0.200)$ & $(0.180)$ & $(0.195)$ & $(0.198)$ & $(0.175)$ \\
\hline$N$ & 1180 & 1180 & 1180 & 1180 & 1180 & 1180 & 1180 & 1180 \\
groups & 48 & 48 & 48 & 48 & 48 & 48 & 48 & 48 \\
N_instr & 6 & 7 & 10 & 13 & 16 & 19 & 20 & 21 \\
AR(1) & 0.001 & 0.001 & 0.000 & 0.000 & 0.000 & 0.000 & 0.000 & 0.000 \\
AR(2) & 0.487 & 0.477 & 0.487 & 0.503 & 0.626 & 0.828 & 0.832 & 0.964 \\
Hansen & 0.620 & 0.277 & 0.546 & 0.567 & 0.616 & 0.574 & 0.563 & 0.739 \\
\hline \hline
\end{tabular}

Standard errors are in brackets. Regressions are based on the Blundell-Bond estimator. Starting from the most parsimonious specification (columns 1-3), we progressively introduce GDP growth, trade, private investment, IMF program, and government stability in columns (4)-(8).

${ }^{*} p<0.1,{ }^{* *} p<0.05,{ }^{* * *} p<0.01$

\subsection{The state of the economy}

First, we consider the state of the economy in the short-run, captured by the phase of the business cycle. Drawing upon the popular Hodrick and Prescott (1997) filter to compute the cyclical component of GDP, we distinguish between "bad" times $\left(C O N S_{i t}^{L C}\right)$ and "good" times $\left(C O N S_{i t}^{H C}\right)$. As shown by Table 7, fiscal consolidations significantly reduce the $G I / G C$ ratio only during bad times, corroborating to some extent our finding of a significant effect exclusively in high-debt contexts.

Second, we look at the state of the economy in the long-run, captured by the development stage. Despite most of the literature being devoted to developed countries, fiscal consolidations may impact differently the composition of public spending in OECD compared with non-OECD emerging countries, given the differences in their respective structural characteristics. Estimations reported in Table 8 show that this is indeed the case: although fiscal consolidations significantly 
Table 7 - The effect of fiscal consolidations on GI/GC: the phase of the business cycle

\begin{tabular}{lcccccccc}
\hline \hline & $(1)$ & $(2)$ & $(3)$ & $(4)$ & $(5)$ & $(6)$ & $(7)$ & $(8)$ \\
\hline$G I_{i t-1}$ & $0.942^{* * *}$ & $0.877^{* * *}$ & $0.958^{* * *}$ & $0.958^{* * *}$ & $0.929^{* * *}$ & $0.950^{* * *}$ & $0.957^{* * *}$ & $0.828^{* * *}$ \\
& $(0.140)$ & $(0.197)$ & $(0.063)$ & $(0.067)$ & $(0.053)$ & $(0.086)$ & $(0.082)$ & $(0.056)$ \\
& & & & & & & & \\
CON $S^{L C}$ & $-0.705^{* * *}$ & & $-0.741^{* * *}$ & $-0.622^{* *}$ & $-0.650^{* *}$ & $-0.590^{* *}$ & $-0.584^{* *}$ & $-0.648^{* * *}$ \\
& $(0.266)$ & & $(0.273)$ & $(0.292)$ & $(0.277)$ & $(0.266)$ & $(0.264)$ & $(0.215)$ \\
& & & & & & & & \\
CON $S^{H C}$ & & -0.272 & -0.335 & -0.304 & -0.355 & -0.974 & -0.895 & -0.118 \\
& & $(0.254)$ & $(0.208)$ & $(0.260)$ & $(0.268)$ & $(0.653)$ & $(0.598)$ & $(0.137)$ \\
\hline$N$ & 1151 & 1151 & 1151 & 1151 & 1151 & 1151 & 1151 & 1151 \\
groups & 48 & 48 & 48 & 48 & 48 & 48 & 48 & 48 \\
N_instr & 7 & 8 & 11 & 14 & 15 & 28 & 29 & 22 \\
AR(1) & 0.001 & 0.004 & 0.000 & 0.000 & 0.000 & 0.000 & 0.000 & 0.000 \\
AR(2) & 0.649 & 0.655 & 0.461 & 0.442 & 0.543 & 0.770 & 0.766 & 0.735 \\
Hansen & 0.572 & 0.406 & 0.608 & 0.473 & 0.644 & 0.747 & 0.792 & 0.374 \\
\hline \hline
\end{tabular}

Standard errors are in brackets. Regressions are based on the Blundell-Bond estimator. Starting from the most parsimonious specification (columns 1-3), we progressively introduce GDP growth, trade, private investment, IMF program, and government stability in columns (4)-(8).

${ }^{*} p<0.1,{ }^{* *} p<0.05,{ }^{* * *} p<0.01$

Table 8 - The effect of fiscal consolidations on the GI/GC ratio: OECD vs non-OECD countries

\begin{tabular}{lcccc}
\hline \hline & $(1)$ & $(2)$ & $(3)$ & $(4)$ \\
\hline$G I_{i t-1}$ & $0.934^{* * *}$ & $0.895^{* * *}$ & $0.844^{* * *}$ & $0.776^{* * *}$ \\
& $(0.092)$ & $(0.043)$ & $(0.125)$ & $(0.062)$ \\
& & & & \\
CON $S_{i t}$ & $-0.458^{* *}$ & $-0.155^{* * *}$ & $-0.834^{* *}$ & $-0.628^{* *}$ \\
& $(0.229)$ & $(0.055)$ & $(0.349)$ & $(0.257)$ \\
\hline$N$ & 578 & 578 & 573 & 573 \\
groups & 21 & 21 & 27 & 27 \\
N_instr & 8 & 20 & 7 & 19 \\
AR(1) & 0.004 & 0.002 & 0.003 & 0.001 \\
AR(2) & 0.304 & 0.330 & 0.642 & 0.747 \\
Hansen & 0.536 & 0.250 & 0.468 & 0.745 \\
Dvp. stage & OECD & OECD & Non-OECD & Non-OECD \\
\hline \hline
\end{tabular}

Standard errors are in brackets. Regressions are based on the Blundell-Bond estimator. Starting from the most parsimonious specification (columns 1 and 3), we introduce lagged debt, GDP growth, trade, private investment, IMF program, and government stability in columns (2) and (4).

${ }^{*} p<0.1,{ }^{* *} p<0.05,{ }^{* * *} p<0.01$ 
reduce the $G I / G C$ ratio in both OECD and non-OECD countries, the magnitude of the estimated coefficient can be up to four times higher in the latter group of countries (for example, if we compare columns 2 and 4). This may be related to a stronger political instability in non-OECD countries, making governments not to take electoral risks associated with cutting consumption spending.

\subsection{The components of government consumption}

So far, we focused on aggregate government consumption $(G C)$ and investment $(G I)$ spending. We now investigate the effects of fiscal consolidations on more disaggregated government consumption components, expressed in ratio of GDP. First, public wages ( $W A G E$ ) measure the remuneration of public sector employees, and their consolidation may affect the welfare of the population. Second, transfers \& subsidies $(S U B)$ act as a distributional tool of national income, and their consolidation may affect the living standards of the population, and particularly the poor population. Third, health spending $(H E A L T H)$ are related to the healthcare system and social protection. ${ }^{6}$

Table 9 - The effect of fiscal consolidations on the ratio GI/GC-sub-components

\begin{tabular}{|c|c|c|c|}
\hline & $\begin{array}{l}(1) \\
G I \_W A G E\end{array}$ & $\begin{array}{c}(2) \\
G I \_S U B\end{array}$ & $\begin{array}{c}(3) \\
G I \_H E A L T H\end{array}$ \\
\hline $\operatorname{DepVar}_{i t-1}$ & $\begin{array}{c}0.778^{* * *} \\
(0.098)\end{array}$ & $\begin{array}{c}0.490^{* * *} \\
(0.013)\end{array}$ & $\begin{array}{c}0.997^{* * *} \\
(0.017)\end{array}$ \\
\hline$C O N S_{i t}$ & $\begin{array}{l}-0.864^{*} \\
(0.479)\end{array}$ & $\begin{array}{c}13.676^{* *} \\
(6.804)\end{array}$ & $\begin{array}{c}-0.655^{* *} \\
(0.273)\end{array}$ \\
\hline$N$ & 167 & 223 & 732 \\
\hline groups & 17 & 17 & 48 \\
\hline $\mathrm{N}_{\text {_instr }}$ & 16 & 16 & 26 \\
\hline $\mathrm{AR}(1)$ & 0.107 & 0.266 & 0.036 \\
\hline $\operatorname{AR}(2)$ & 0.320 & 0.594 & 0.274 \\
\hline Hansen & 0.312 & 0.681 & 0.318 \\
\hline
\end{tabular}

Standard errors are in brackets. Regressions are based on the Blundell-Bond estimator. Lagged Dep_Var ${ }_{t-1}$ is predetermined, lagged debt, government stability and IMF program are exogenous, and the remaining covariates are endogenous.

${ }^{*} p<0.1,{ }^{* *} p<0.05,{ }^{* * *} p<0.01$

Using these variables, we look at the composition effect. Table 9 shows that the decline in GI is stronger than the contraction of public wages, and health government spending, corroborating our previous results based on aggregate measures of $G C$. However, fiscal consolidations are found to increase the ratio between $G I$ and transfers \& subsidies, suggesting a strong decline of the latter, relatively more important than the decline of the former.

\footnotetext{
${ }^{6}$ While education spending are equally a relevant component of government spending, we exclude them because they encompass both investment and current spending.
} 


\section{Conclusion}

Existing studies emphasize a negative effect of fiscal consolidations on government investment and consumption as ratios of GDP (Balassone and Franco (1999); Castro (2017); De Haan et al. (1996); Turrini (2004); Välilä and Mehrotra (2005)). This paper looked at the effect of fiscal consolidations on the ratio between government investment and consumption. System-GMM estimations performed on a sample of 53 developed and emerging countries during the period 1980-2011 revealed that the contraction of government investment is more important than that of government consumption, i.e. a composition effect is at work, robust to a wide range of alternative specifications.

Given the large impact of both government consumption and investment on the economy documented by the existing literature, we investigated more in detail this composition effect. In particular, we found that public investment may be particularly affected by fiscal consolidations (i.e. its contraction may be stronger than that of public consumption) when debt is high and in the low phase of the economic cycle. Consequently, our findings suggest that caution should be at work in such contexts, during which fiscal consolidations aimed at short-run stabilization may hurt the economy in the long-run through their detrimental effect on public investment. Future work could be devoted to exploring possible mechanisms in the design of fiscal consolidations that may allow avoiding such undesirable consequences. 


\section{References}

Abiad, A., Furceri, D., and Topalova, P. The macroeconomic effects of public investment: Evidence from advanced economies. Journal of Macroeconomics, 50:224-240, 2016.

Afonso, A. and Jalles, J. Measuring the success of fiscal consolidations. Applied Financial Economics, 22:1053-1061, 2012.

Agnello, L. and Sousa, R. How does fiscal consolidation impact on income inequality?. Review of Income and Wealth, 60:702-726, 2014.

Alesina, A. and Ardagna, S. Tales of fiscal adjustment. Economic Policy, 13:488-545, 1998.

Alesina, A. and Ardagna, S. Large changes in fiscal policy: Taxes versus Spending. Tax Policy and the Economy, 24:35-68, 2010.

Alesina, A. and Ardagna, S. The design of fiscal adjustments. Tax Policy and the Economy, 27: 19-68, 2013.

Alesina, A. and Perotti, R. Fiscal expansions and adjustments in OECD countries. Economic Policy, 10:205-248, 1995.

Alesina, A. and Perotti, R. Fiscal adjustments in OECD countries: Composition and macroeconomic effects. IMF Staff Papers, 44:210-248, 1997.

Alesina, A., Favero, C., and Giavazzi, F. The output effect of fiscal consolidation plans. Journal of International Economics, 96:S19-S42, 2015.

Alesina, A., Azzalini, G., Favero, C., Giavazzi, F., and Miano, A. Is it the "how" or the "when" that matters in fiscal adjustments?. IMF Economic Review, 66:144-188, 2018.

Alonso-Borrego, C. and Arellano, M. Symmetrically normalized instrumental-variable estimation using panel data. Journal of Business \& Economic Statistics, 17:36-49, 1999.

Ardagna, S. Fiscal stabilizations: When do they work and why. European Economic Review, 48:1047-1074, 2004.

Aschauer, D. Is public expenditure productive?. Journal of Monetary Economics, 23:177200,1989

Bacchiocchi, E., Borghi, E., and Missale, A. Public investment under fiscal constraints. Fiscal Studies, 32:11-42, 2011.

Balassone, F. and Franco, D. Public investment in the Stability Pact framework. Concorrenza fiscale in un'economia internazionale integrata, Milano: Franco Angeli, 1999.

Barrios, S., Langedijk, S., and Pench, L. EU fiscal consolidation after the financial crisis Lessons from past experiences. Paper Presented at the 12th Banca d'Italia Public Finance Workshop "Fiscal Policy: Lessons from the Crisis" held in Perugia on 25-27 March, 2010. 
Blanchard, O. Suggestions for a new set of fiscal indicators. OECD Economic Department Working Papers No.79, 1990.

Blanchard, O. and Giavazzi, F. Improving the SGP through a proper accounting of public investment. CEPR Discussion Paper No.4220, 2004.

Blundell, R. and Bond, S. Initial conditions and moment restrictions in dynamic panel data models. Journal of Econometrics, 87:115-143, 1998.

Blundell, R., Bond, S., and Windmeijer, F. Estimation in dynamic panel data models: Improving on the performance of the standard GMM estimator. In Nonstationary Panels, Panel Cointegration, and Dynamic Panels, pages 53-91. Emerald Group Publishing Limited, 2001.

Castro, V. The impact of fiscal consolidations on the functional components of government expenditures. Economic Modelling, 60:138-150, 2017.

Cotis, J.-P., Elmeskov, J., and Mourougane, A. Estimates of potential output: benefits and pitfalls from a policy perspective. In The euro area business cycle: stylized facts and measurement issues, pages 35-60. CEPR, London, 2004.

David, A. C. and Leigh, D. A new action-based dataset of fiscal consolidation in Latin America and the Caribbean. IMF Working Paper No. WP/18/94, 2018.

De Haan, J., Sturm, J., and Sikken, B. Government capital formation: Explaining the decline. Review of World Economics, 132:55-74, 1996.

Devries, P., Guajardo, J., Leigh, D., and Pescatori, A. A new action-based dataset of fiscal consolidation. IMF Working Paper No. 11/128., 2011.

Drazen, A. [Can Severe Fiscal Contractions Be Expansionary? Tales of Two Small European Countries]: Comment. NBER Macroeconomics Annual, 5:117-122, 1990.

Friedman, M. and Schwartz, A. J. A Monetary history of the United States 1867-1960. Princeton University Press, 1963.

Giavazzi, F. and Pagano, M. Non-Keynesian Effects of Fiscal Policy Changes: International Evidence and the Swedish Experience. NBER Working Paper No. 5332, 1995.

Guajardo, J., Leigh, D., and Pescatori, A. Expansionary austerity? International evidence. Journal of the European Economic Association, 12:949-968, 2014.

Hauk, W. and Wacziarg, R. A Monte Carlo study of growth regressions. Journal of Economic Growth, 14:103-147, 2009.

Heijdra, B. and Meijdam, L. Public investment and intergenerational distribution. Journal of Economic Dynamics and Control, 26:707-735, 2002.

Heylen, F. and Everaert, G. Success and failure of fiscal consolidation in the OECD: A multivariate analysis. Public Choice, 105:103-124, 2000. 
Heylen, F., Hoebeeck, A., and Buyse, T. Government efficiency, institutions, and the effects of fiscal consolidation on public debt. European Journal of Political Economy, 31:40-59, 2013.

Hodrick, R. and Prescott, E. Postwar US business cycles: an empirical investigation. Journal of Money, Credit, and Banking, 29:1-16, 1997.

IMF. Is it time for an infrastructure push? The Macroeconomic Effects of Public Investment. IMF World Economic Outlook, ch.3. Washington, DC, USA, 2014.

IMF. Making public investment more efficient. IMF Policy Paper, 2015.

IMF. Investment and capital stock dataset, 1960-2015, January 2017.

Leigh, D., Devries, P., Freedman, C., Guajardo, J., Laxton, D., and Pescatori, A. Will it hurt? Macroeconomic effects of fiscal consolidation. IMF World Economic Outlook, 93: $124,2010$.

Mauro, P., Romeu, R., Binder, A., and Zaman, A. A modern history of fiscal prudence and profligacy. Journal of Monetary Economics, 76:55-70, 2015.

McDermott, J. and Wescott, R. An empirical analysis of fiscal adjustments. IMF Staff Papers, 43:725-753, 1996.

Minea, A. and Villieu, P. Borrowing to Finance Public Investment? The 'Golden Rule of Public Finance' Reconsidered in an Endogenous Growth Setting. Fiscal Studies, 30: 103-133, 2009.

Musgrave, R. The nature of budgetary balance and the case for the capital budget. The American Economic Review, 29:260-271, 1939.

Nickell, S. Biases in dynamic models with fixed effects. Econometrica, 49:1417-1426, 1981.

Oxley, H. and Martin, J. Controlling Government Spending and Deficits: Trends in the 1980s and Prospects for the 1990s. OECD Economic Studies, 17:145-189, 1991.

Romer, C. D. and Romer, D. H. Does monetary policy matter? A new test in the spirit of Friedman and Schwartz. NBER Macroeconomics Annual, 4:121-170, 1989.

Roodman, D. A note on the theme of too many instruments. Oxford Bulletin of Economics and Statistics, 71:135-158, 2009.

Roubini, N. and Sachs, J. Political and economic determinants of budget deficits in the industrial democracies. European Economic Review, 33:903-933, 1989.

Schaltegger, C. and Feld, L. Are fiscal adjustments less successful in decentralized governments?. European Journal of Political Economy, 25:115-123, 2009.

Turrini, A. Public investment and the EU fiscal framework. European Economy-Economic Paper No. 202, 2004. 
Välilä, T. and Mehrotra, A. Evolution and determinants of public investment in Europe. European Ivestment Bank - Economic and Financial Report No. 2005/01, 2005.

Yang, W., Fidrmuc, J., and Ghosh, S. Macroeconomic effects of fiscal adjustment: A tale of two approaches. Journal of International Money and Finance, 57:31-60, 2015. 


\section{A Appendix}

Table 10 - Episodes of fiscal consolidations

\begin{tabular}{|c|c|c|}
\hline Countries & Adjustment periods & number \\
\hline Argentina & $1984-1985 ; 1991-1993 ; 2002-2004$ & 3 \\
\hline Australia & $1983-1988 ; 1993-1997$ & 2 \\
\hline Austria & $1996-1997 ; 2000-2001$ & 2 \\
\hline Belgium & 1984-1987; 1993-1995 & 2 \\
\hline Bolivia & $2003-2006$ & 1 \\
\hline Brazil & $1999-2000$ & 1 \\
\hline Bulgaria & $2000-2001 ; 2010-2011$ & 2 \\
\hline Canada & $1981-1982 ; 1990-1997$ & 2 \\
\hline Chile & 1987-1989; 1994-1995; 2003-2006; 2010-2011 & 4 \\
\hline China & $2004-2007$ & 1 \\
\hline Colombia & $1985-1987 ; 2000-2001 ; 2003-2004$ & 3 \\
\hline Costa Rica & $1981-1982 ; 1991-1992 ; 1995-1997$ & 3 \\
\hline Denmark & $1983-1986 ; 2003-2005$ & 2 \\
\hline Dominican Republic & $2004-2007$ & 1 \\
\hline Finland & 1984-1985; 1988-1989; 1993-1994; 1996-1998 & 4 \\
\hline France & $1994-1999 ; 2010-2011$ & 2 \\
\hline Germany & $1982-1985 ; 1996-2000 ; 2004-2007$ & 3 \\
\hline Greece & $1986-1987 ; 1990-1991 ; 2005-2006$ & 3 \\
\hline Honduras & $1985-1989,1995-1996 ; 2003-2004$ & 3 \\
\hline Hong kong & $2006-2007 ; 2009-2010$ & 2 \\
\hline Hungary & 1999-2000; 2003-2004; 2007-2008 & 3 \\
\hline Iceland & $1990-1992 ; 2004-2006$ & 2 \\
\hline Indonesia & $1989-1990$ & 1 \\
\hline Iran & $2003-2004$ & 1 \\
\hline Ireland & $1986-1989$ & 1 \\
\hline Israel & $1993-1995 ; 1997-2000 ; 2004-2007$ & 3 \\
\hline Italy & $1982-1983 ; 1988-1992 ; 1995-1997 ; 2006-2007$ & 4 \\
\hline Japan & $1981-1987$ & 1 \\
\hline Mexico & 1983-1984; 1986-1989 & 2 \\
\hline Netherlands & $1981-1985 ; 2004-2006$ & 2 \\
\hline New Zealand & $1985-1988 ; 1992-1995 ; 2000-2005$ & 3 \\
\hline Nicaragua & $1991-1992 ; 1997-1998 ; 2010-2011$ & 3 \\
\hline Norway & $1981-1985 ; 1988-1990 ; 1993-1996 ; 1999-2000 ; 2004-2006$ & 5 \\
\hline Pakistan & 1988-1990;1993-1994; 1998-1999; 2006-2007 & 4 \\
\hline Panama & $1985-1986 ; 1989-1990 ; 2005-2007$ & 3 \\
\hline Paraguay & $1985-1986 ; 1989-1990 ; 1993-1994 ; 2003-2004$ & 4 \\
\hline Peru & 1984-1985; 1988-1989; 2004-2007; 2010-2011 & 4 \\
\hline Portugal & $1981-1984 ; 2002-2003 ; 2006-2007 ; 2010-2011$ & 4 \\
\hline Romania & $1997-1998 ; 2010-2011$ & 2 \\
\hline Russia & $2003-2005 ; 2010-2011$ & 2 \\
\hline South Africa & $1994-1995 ; 1998-1999 ; 2004-2007$ & 3 \\
\hline South Korea & $1995-2000$ & 1 \\
\hline Spain & $1983-1988 ; 2010-2011$ & 2 \\
\hline Sweden & $1981-1987 ; 1993-1998 ; 2004-2005$ & 3 \\
\hline Switzerland & $1992-1996 ; 2005-2006$ & 2 \\
\hline Turkey & $1981-1983 ; 1994-1995 ; 1998-1999 ; 2002-2005$ & 4 \\
\hline United Kingdom & $1981-1986 ; 1995-2000 ; 2010-2011$ & 3 \\
\hline United States & 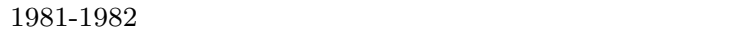 & 1 \\
\hline Uruguay & $1985-1986 ; 1990-1991 ; 2000-2005$ & 3 \\
\hline \multirow[t]{2}{*}{ Venezuela } & $2002-2005$ & 1 \\
\hline & Total & 123 \\
\hline
\end{tabular}


Table 11 - Description of the variables

\begin{tabular}{|c|c|c|}
\hline Variables & Descriptions & Sources \\
\hline GI & Public investment in $\%$ of GDP & Authors' estimations based on (IMF, 2017) \\
\hline GC & Government consumption in $\%$ of GDP & Authors' estimations based on WDI database \\
\hline CONS & $\begin{array}{l}\text { Change in CAPB in fiscal consolidation stance } \\
\text { and zero otherwise }\end{array}$ & Authors' estimations \\
\hline NCONS & $\begin{array}{l}\text { Change in CAPB out of fiscal consolidations } \\
\text { periods and zero otherwise }\end{array}$ & Authors' estimations \\
\hline $\mathrm{CONS}^{\mathrm{HD}}$ & $\begin{array}{l}\text { Change in CAPB during high-debt based fis- } \\
\text { cal consolidations and zero otherwise }\end{array}$ & Authors' estimations \\
\hline $\mathrm{CONS}^{\mathrm{LD}}$ & $\begin{array}{l}\text { Change in CAPB during low-debt based fiscal } \\
\text { consolidations and zero otherwise }\end{array}$ & Authors' estimations \\
\hline $\mathrm{CONS}^{\mathrm{HC}}$ & $\begin{array}{l}\text { Change in CAPB during fiscal consolidations } \\
\text { in boom and zero otherwise }\end{array}$ & Authors' estimations \\
\hline $\mathrm{CONS}^{\mathrm{LC}}$ & $\begin{array}{l}\text { Change in CAPB during fiscal consolidations } \\
\text { in slump and zero otherwise }\end{array}$ & Authors' estimations \\
\hline DEBT & Total debt in $\%$ of GDP & Mauro et al. (2015) \\
\hline GROWTH & Real GDP growth rate & WDI database \\
\hline IPRIV & Private investment in \% of GDP & $(\mathrm{IMF}, 2017)$ \\
\hline FDI & Foreign direct investment in $\%$ of GDP & WDI database \\
\hline AID & Total aid in $\%$ of GNI & WDI database \\
\hline TRADE & Imports plus exports in $\%$ du GDP & WDI database \\
\hline EXECL & $\begin{array}{l}\text { Dummy variable equal to } 1 \text { if it is a left-wing } \\
\text { government and zero otherwise }\end{array}$ & Authors' estimations based on DPI 2015 \\
\hline PCOL & $\begin{array}{l}\text { Dummy variable equal to } 1 \text { if legislature and } \\
\text { government are led by different parties and } \\
\text { zero otherwise }\end{array}$ & Authors' estimations based on DPI 2015 \\
\hline EXELEC & $\begin{array}{l}\text { Dummy variable equal to } 1 \text { in the electoral } \\
\text { period and zero otherwise }\end{array}$ & Authors' estimations based on DPI 2015 \\
\hline IMFP & $\begin{array}{l}\text { Dummy variable equal to } 1 \text { if the country is } \\
\text { under IMF program and zero otherwise }\end{array}$ & MONA Database \\
\hline SUB & Subsidies and transfers in $\%$ of GDP & WDI database \\
\hline GOV & Government stability index & ICRG Database \\
\hline CONS_L & $\begin{array}{l}\text { Interactive term between fiscal consolidations } \\
\text { and the left-wing government dummy }\end{array}$ & Authors' estimations \\
\hline$\frac{\text { GI }}{\text { GC }}$ & $\begin{array}{l}\text { Public investment to government consumption } \\
\text { ratio }\end{array}$ & Authors' estimations \\
\hline$\frac{\text { SUB }}{\text { GC }}$ & $\begin{array}{l}\text { Subsidies and transfers to government con- } \\
\text { sumption ratio }\end{array}$ & Authors' estimations \\
\hline$\frac{\text { GI }}{\text { SUB }}$ & $\begin{array}{l}\text { Public investment to subsidies and transfers } \\
\text { ratio }\end{array}$ & Authors' estimations \\
\hline$\frac{\text { GI }}{\text { HEALTH }}$ & $\begin{array}{l}\text { Public investment to government health } \\
\text { spending ratio }\end{array}$ & Authors' estimations \\
\hline$\frac{\text { GI }}{\text { WAGE }}$ & Public investment to wages ratio & Authors' estimations \\
\hline
\end{tabular}


Table 12 - Summary statistics

\begin{tabular}{lccccc}
\hline \hline & count & mean & sd & $\min$ & $\max$ \\
\hline GI & 1455 & 4.1 & 2.5 & 0.2 & 21.9 \\
GC & 1333 & 16.2 & 4.8 & 3.0 & 43.5 \\
CONS & 1393 & 0.5 & 1.1 & 0 & 13.5 \\
NCONS & 1393 & -0.5 & 2.0 & -14.0 & 21.7 \\
CONS & 1393 & 0.2 & 0.9 & 0 & 13.2 \\
CONS $^{\text {LD }}$ & 1393 & 0.2 & 0.7 & 0 & 9.7 \\
CONS & 1393 & 0.2 & 0.7 & 0 & 9.7 \\
CONS & 1393 & 0.3 & 1.0 & 0 & 13.5 \\
DEBT & 1438 & 54.9 & 32.6 & 4.1 & 231.0 \\
GROWTH & 1449 & 3.2 & 3.5 & -13.4 & 18.3 \\
IPRIV & 1455 & 15.8 & 5.5 & 0.4 & 36.2 \\
FDI & 1321 & 2.8 & 5.1 & -16.1 & 87.4 \\
AID & 609 & 1.7 & 4.8 & -0.7 & 72.1 \\
TRADE & 1340 & 63.4 & 31.7 & 11.5 & 190.1 \\
EXECL & 1230 & 0.3 & 0.5 & 0 & 1 \\
PCOL & 1360 & 0.1 & 0.3 & 0 & 1 \\
EXELEC & 1393 & 0.1 & 0.3 & 0 & 1 \\
IMFP & 1448 & 0.2 & 0.4 & 0 & 1 \\
SUB & 882 & 14.7 & 14.5 & 0.007 & 339.6 \\
GOV & 1312 & 7.8 & 1.8 & 1 & 12 \\
CONS_L & 1190 & 0.2 & 0.6 & 0 & 7.3 \\
GI & 1333 & 28.7 & 22.2 & 1.4 & 203.7 \\
GC & 881 & 86.8 & 140.2 & 0.05 & 3955.5 \\
GU & 261 & 1655.8 & 19670.1 & -160.0 & 315551.7 \\
GI & 860 & 64.8 & 61.7 & 5.5 & 500.3 \\
HEGI & 200 & 56.2 & 41.3 & -63.3 & 228.7 \\
GEI & WAGE & & & & \\
\hline \hline
\end{tabular}


Table 13 - The effect of fiscal consolidation on the government investment to GDP ratio

\begin{tabular}{|c|c|c|c|c|c|c|c|c|}
\hline & (1) & $(2)$ & (3) & (4) & (5) & (6) & (7) & (8) \\
\hline & BB & BB & BB & BB & BB & $\mathrm{BB}$ & BB & $\mathrm{BB}$ \\
\hline$G I_{i t-1}$ & $\begin{array}{c}0.785^{* * *} \\
(0.192)\end{array}$ & $\begin{array}{c}0.871^{* * *} \\
(0.080)\end{array}$ & $\begin{array}{c}0.884^{* * *} \\
(0.081)\end{array}$ & $\begin{array}{c}0.774^{* * *} \\
(0.178)\end{array}$ & $\begin{array}{c}0.772^{* * *} \\
(0.159)\end{array}$ & $\begin{array}{c}0.647^{* * *} \\
(0.146)\end{array}$ & $\begin{array}{c}0.718^{* * *} \\
(0.132)\end{array}$ & $\begin{array}{c}0.770^{* * *} \\
(0.119)\end{array}$ \\
\hline$C O N S_{i t}$ & $\begin{array}{c}-0.077^{* *} \\
(0.036)\end{array}$ & $\begin{array}{c}-0.081^{* * *} \\
(0.028)\end{array}$ & $\begin{array}{c}-0.081^{* * *} \\
(0.030)\end{array}$ & $\begin{array}{c}-0.098^{* * *} \\
(0.034)\end{array}$ & $\begin{array}{c}-0.095^{* * *} \\
(0.028)\end{array}$ & $\begin{array}{l}-0.068^{*} \\
(0.037)\end{array}$ & $\begin{array}{c}-0.100^{* * *} \\
(0.032)\end{array}$ & $\begin{array}{c}-0.100^{* * *} \\
(0.024)\end{array}$ \\
\hline$G C_{i t}$ & & $\begin{array}{c}-0.024 \\
(0.036)\end{array}$ & $\begin{array}{l}-0.028 \\
(0.034)\end{array}$ & $\begin{array}{l}-0.015 \\
(0.049)\end{array}$ & $\begin{array}{l}-0.012 \\
(0.047)\end{array}$ & $\begin{array}{c}0.017 \\
(0.062)\end{array}$ & $\begin{array}{l}-0.038 \\
(0.049)\end{array}$ & $\begin{array}{l}-0.052 \\
(0.041)\end{array}$ \\
\hline$D E B T_{i t-1}$ & & & $\begin{array}{c}-0.002 \\
(0.004)\end{array}$ & $\begin{array}{l}-0.003 \\
(0.005)\end{array}$ & $\begin{array}{l}-0.003 \\
(0.004)\end{array}$ & $\begin{array}{c}-0.003 \\
(0.004)\end{array}$ & $\begin{array}{c}-0.001 \\
(0.004)\end{array}$ & $\begin{array}{l}-0.001 \\
(0.003)\end{array}$ \\
\hline$G R O W T H_{i t}$ & & & & $\begin{array}{c}-0.051^{*} \\
(0.030)\end{array}$ & $\begin{array}{c}-0.049^{*} \\
(0.028)\end{array}$ & $\begin{array}{l}-0.035 \\
(0.030)\end{array}$ & $\begin{array}{c}-0.005 \\
(0.013)\end{array}$ & $\begin{array}{l}-0.004 \\
(0.012)\end{array}$ \\
\hline$T R A D E_{i t}$ & & & & & $\begin{array}{l}-0.001 \\
(0.004)\end{array}$ & $\begin{array}{l}-0.009 \\
(0.013)\end{array}$ & $\begin{array}{c}-0.002 \\
(0.003)\end{array}$ & $\begin{array}{l}-0.001 \\
(0.003)\end{array}$ \\
\hline$I P R I V_{i t}$ & & & & & & $\begin{array}{l}-0.020 \\
(0.073)\end{array}$ & $\begin{array}{c}-0.084^{* *} \\
(0.038)\end{array}$ & $\begin{array}{c}-0.087^{* *} \\
(0.034)\end{array}$ \\
\hline$I M F P_{i t}$ & & & & & & & $\begin{array}{c}-0.285^{*} \\
(0.169)\end{array}$ & $\begin{array}{c}-0.329^{* *} \\
(0.153)\end{array}$ \\
\hline$S U B_{i t}$ & & & & & & & $\begin{array}{c}-0.006 \\
(0.005)\end{array}$ & $\begin{array}{l}-0.007 \\
(0.005)\end{array}$ \\
\hline$G O V_{i t}$ & & & & & & & & $\begin{array}{c}0.009 \\
(0.011)\end{array}$ \\
\hline$N$ & 817 & 817 & 817 & 817 & 817 & 817 & 817 & 817 \\
\hline groups & 43 & 43 & 43 & 43 & 43 & 43 & 43 & 43 \\
\hline $\mathrm{N}$ _instr & 8 & 7 & 8 & 9 & 12 & 13 & 21 & 22 \\
\hline $\mathrm{AR}(1)$ & 0.003 & 0.000 & 0.000 & 0.001 & 0.000 & 0.003 & 0.000 & 0.000 \\
\hline $\operatorname{AR}(2)$ & 0.501 & 0.464 & 0.513 & 0.356 & 0.351 & 0.293 & 0.453 & 0.480 \\
\hline Hansen & 0.130 & 0.129 & 0.146 & 0.286 & 0.549 & 0.445 & 0.707 & 0.815 \\
\hline
\end{tabular}

Standard errors are in brackets. Regressions are based on the Blundell-Bond estimator. Lagged GI is predetermined, lagged debt is exogenous, and the remaining covariates are endogenous variables.

${ }^{*} p<0.1,{ }^{* *} p<0.05,{ }^{* * *} p<0.01$ 
Table 14 - The effect of fiscal consolidation on the government consumption to GDP ratio

\begin{tabular}{|c|c|c|c|c|c|c|c|c|}
\hline & (1) & $(2)$ & $(3)$ & $(4)$ & $(5)$ & $(6)$ & $(7)$ & $(8)$ \\
\hline$G C_{i t-1}$ & $\begin{array}{c}0.893^{* * *} \\
(0.049)\end{array}$ & $\begin{array}{c}0.834^{* * *} \\
(0.063)\end{array}$ & $\begin{array}{c}0.836^{* * *} \\
(0.058)\end{array}$ & $\begin{array}{c}0.723^{* * *} \\
(0.058)\end{array}$ & $\begin{array}{c}0.845^{* * *} \\
(0.064)\end{array}$ & $\begin{array}{c}0.855^{* * *} \\
(0.062)\end{array}$ & $\begin{array}{c}0.840^{* * *} \\
(0.049)\end{array}$ & $\begin{array}{c}0.857^{* * *} \\
(0.039)\end{array}$ \\
\hline$C O N S_{i t}$ & $\begin{array}{c}-0.182^{* * *} \\
(0.059)\end{array}$ & $\begin{array}{c}-0.173^{* *} \\
(0.085)\end{array}$ & $\begin{array}{c}-0.181^{* *} \\
(0.091)\end{array}$ & $\begin{array}{c}-0.103^{* *} \\
(0.046)\end{array}$ & $\begin{array}{c}-0.136^{* *} \\
(0.054)\end{array}$ & $\begin{array}{c}-0.137^{* *} \\
(0.057)\end{array}$ & $\begin{array}{c}-0.167^{* *} \\
(0.069)\end{array}$ & $\begin{array}{c}-0.159^{* *} \\
(0.070)\end{array}$ \\
\hline$G I_{i t}$ & & $\begin{array}{c}0.474^{*} \\
(0.261)\end{array}$ & $\begin{array}{c}0.444^{* *} \\
(0.225)\end{array}$ & $\begin{array}{c}0.416^{*} \\
(0.232)\end{array}$ & $\begin{array}{c}0.333^{*} \\
(0.171)\end{array}$ & $\begin{array}{c}0.302^{*} \\
(0.163)\end{array}$ & $\begin{array}{l}0.317^{*} \\
(0.178)\end{array}$ & $\begin{array}{c}0.316^{* *} \\
(0.152)\end{array}$ \\
\hline$D E B T_{i t-1}$ & & & $\begin{array}{c}0.004 \\
(0.008)\end{array}$ & $\begin{array}{c}0.009 \\
(0.010)\end{array}$ & $\begin{array}{c}0.001 \\
(0.007)\end{array}$ & $\begin{array}{c}0.000 \\
(0.008)\end{array}$ & $\begin{array}{c}-0.005 \\
(0.008)\end{array}$ & $\begin{array}{c}-0.001 \\
(0.013)\end{array}$ \\
\hline$G_{R O W T H_{i t}}$ & & & & $\begin{array}{c}-0.128^{* * *} \\
(0.031)\end{array}$ & $\begin{array}{c}-0.087^{* * *} \\
(0.023)\end{array}$ & $\begin{array}{c}-0.081^{* * *} \\
(0.026)\end{array}$ & $\begin{array}{c}-0.088^{* * *} \\
(0.030)\end{array}$ & $\begin{array}{c}-0.096^{* * *} \\
(0.031)\end{array}$ \\
\hline$T R A D E_{i t}$ & & & & & $\begin{array}{c}-0.028^{* * *} \\
(0.009)\end{array}$ & $\begin{array}{c}-0.028^{* * *} \\
(0.009)\end{array}$ & $\begin{array}{c}-0.020^{* *} \\
(0.010)\end{array}$ & $\begin{array}{c}-0.025^{* * *} \\
(0.010)\end{array}$ \\
\hline$I P R I V_{i t}$ & & & & & & $\begin{array}{c}-0.024 \\
(0.029)\end{array}$ & $\begin{array}{c}-0.048 \\
(0.033)\end{array}$ & $\begin{array}{l}-0.027 \\
(0.037)\end{array}$ \\
\hline$I M F P_{i t}$ & & & & & & & $\begin{array}{c}-0.518^{* *} \\
(0.205)\end{array}$ & $\begin{array}{c}-0.456^{* *} \\
(0.180)\end{array}$ \\
\hline$S U B_{i t}$ & & & & & & & $\begin{array}{c}-0.003^{*} \\
(0.002)\end{array}$ & $\begin{array}{l}-0.001 \\
(0.001)\end{array}$ \\
\hline$G O V_{i t}$ & & & & & & & & $\begin{array}{c}0.032 \\
(0.028)\end{array}$ \\
\hline$N$ & 817 & 817 & 817 & 817 & 817 & 817 & 817 & 817 \\
\hline groups & 43 & 43 & 43 & 43 & 43 & 43 & 43 & 43 \\
\hline $\mathrm{N} \_$instr & 20 & 12 & 13 & 12 & 20 & 21 & 28 & 24 \\
\hline $\mathrm{AR}(1)$ & 0.008 & 0.009 & 0.005 & 0.013 & 0.008 & 0.008 & 0.006 & 0.009 \\
\hline $\operatorname{AR}(2)$ & 0.369 & 0.717 & 0.305 & 0.463 & 0.411 & 0.464 & 0.582 & 0.340 \\
\hline Hansen & 0.508 & 0.177 & 0.169 & 0.521 & 0.280 & 0.261 & 0.219 & 0.327 \\
\hline
\end{tabular}

Standard errors are in brackets. Regressions are based on the Blundell-Bond estimator. Lagged $G C$ is predetermined, GDP growth and fiscal consolidation are endogenous, and the remaining covariates are exogenous.

${ }^{*} p<0.1,{ }^{* *} p<0.05,{ }^{* * *} p<0.01$ 
Table 15 - The effect of fiscal consolidations on the GI/GC ratio: other controls

\begin{tabular}{|c|c|c|c|}
\hline & (1) & $(2)$ & $(3)$ \\
\hline$\frac{G I_{i t-1}}{G C_{i t-1}}$ & $\begin{array}{c}0.907^{* * *} \\
(0.113)\end{array}$ & $\begin{array}{c}0.875^{* * *} \\
(0.096)\end{array}$ & $\begin{array}{c}0.759^{* * *} \\
(0.047)\end{array}$ \\
\hline$C O N S_{i t}$ & $\begin{array}{c}-1.226^{* * *} \\
(0.341)\end{array}$ & $\begin{array}{c}-0.727^{* * *} \\
(0.220)\end{array}$ & $\begin{array}{c}-2.587^{*} \\
(1.441)\end{array}$ \\
\hline$F D I$ & $\begin{array}{c}0.143 \\
(0.297)\end{array}$ & & \\
\hline$A I D$ & & $\begin{array}{l}0.345^{* *} \\
(0.152)\end{array}$ & \\
\hline$D E B T_{i t-1}$ & & & $\begin{array}{c}0.016 \\
(0.015)\end{array}$ \\
\hline PCOL & & & $\begin{array}{c}-0.720 \\
(1.211)\end{array}$ \\
\hline$E X E C L$ & & & $\begin{array}{l}-1.606 \\
(1.927)\end{array}$ \\
\hline$E X E L E C$ & & & $\begin{array}{l}-1.926^{*} \\
(1.047)\end{array}$ \\
\hline CONS_L & & & $\begin{array}{c}2.198 \\
(1.627)\end{array}$ \\
\hline$N$ & 328 & 328 & 328 \\
\hline groups & 16 & 16 & 16 \\
\hline $\mathrm{N}_{\text {_instr }}$ & 12 & 8 & 12 \\
\hline $\mathrm{AR}(1)$ & 0.014 & 0.015 & 0.009 \\
\hline $\mathrm{AR}(2)$ & 0.102 & 0.103 & 0.178 \\
\hline Hansen & 0.643 & 0.585 & 0.733 \\
\hline
\end{tabular}

Standard errors in parentheses

${ }^{*} p<0.1,{ }^{* *} p<0.05,{ }^{* * *} p<0.01$ 